\title{
Academic Misconduct within Higher Education in Canada
}

\author{
Julia M. Christensen Hughes \\ University of Guelph \\ Donald L. McCabe \\ Rutgers University
}

\begin{abstract}
Despite a plethora of research on the academic misconduct carried out by U.S. high school and undergraduate university students, little research has been done on the academic misconduct of Canadian students. This paper addresses this shortcoming by presenting the results of a study conducted at 11 Canadian higher education institutions between January 2002 and March 2003. We maintain that academic misconduct does indeed occur in Canada - amongst high school, undergraduate and graduate students. Common self-reported behaviours were as follows: working on an assignment with others when asked for individual work, getting questions and answers from someone who has already taken a test, copying a few sentences of material without footnoting, fabricating or falsifying lab data, and receiving unauthorized help on an assignment. Possible factors associated with these behaviours include student maturity, perceptions of what constitutes academic misconduct, faculty assessment and invigilation practices, low perceived risk, ineffective and poorly understood policies and procedures, and a lack of education on academic misconduct. Canadian educational institutions are encouraged to address these issues, beginning with a recommitment to academic integrity.
\end{abstract}

\section{RÉSUMÉ}

Malgré l'abondance de recherches sur la probité intellectuelle parmi les étudiantes et les étudiants de l'enseignement secondaire et universitaire 
aux États-Unis, peu de recherches ont été effectuées sur ce sujet au Canada. Cet article vise à combler cette lacune en présentant les résultats d'une étude entreprise dans 11 établissements d'enseignement supérieur au Canada entre janvier 2002 et mars 2003. Selon les résultats de l'étude, des manques à la probité intellectuelle se produisent en effet au Canada, tant dans l'enseignement secondaire qu'au premier cycle et aux cycles supérieurs des universités. Les comportements les plus fréquemment rapportés par les répondants sont: travailler avec d'autres sur une tâche individuelle; obtenir des questions et réponses de personnes qui ont déjà passé un examen; plagier; fabriquer ou falsifier des données de laboratoire; et recevoir une aide interdite dans l'accomplissement d'une tâche. Ces comportements peuvent être associés à divers facteurs: la maturité de l'étudiante ou de l'étudiant; la perception de la gravité du comportement en question; les pratiques d'évaluation et de surveillance du corps enseignant ; la perception du niveau de risque; la clarté et l'efficacité des procédures établies; et à un manque d'éducation sur les questions de conduite universitaire. Les établissements d'enseignement canadiens sont encouragés à tenter de résoudre ces problèmes, en commençant par renouveler leur engagement envers la probité intellectuelle.

Academic misconduct has become widely recognized as a significant problem amongst American high school and university students, but it is not known to what extent academic misconduct is a problem amongst Canadian high school and university students. This paper attempts to address this question by presenting the results of a study conducted at 11 Canadian higher education institutions (10 universities and one degree-granting college) between January 2002 and March 2003. We argue that academic misconduct does indeed occur in Canada amongst high school, undergraduate and graduate students and that both Canadian high schools and the higher education system need to recommit to the principles of academic integrity.

\section{Academic Misconduct in the U.S.: Common Behaviours and Explanations}

U.S.-based research has consistently shown that a majority of undergraduate students have engaged in some form of academic misconduct while at college or university (see for example, Bowers, 1964; Davis, Grover, Becker \& McGregor, 1992; Haines, Diekhoff, LaBeff and Clark, 1986; Hetherington \& Feldman, 1964; Jendrek, 1992; McCabe \& Trevino, 1993; Payne \& Nantz, 1994; Singhal, 1982). Within these studies, academic misconduct has generally been understood to include cheating during examinations (e.g., looking at another student's work, using crib notes) or on written work (e.g., plagiarism, unpermitted collaboration). 
Recently, U.S. research has also shown that some forms of academic misconduct may be increasing. For example, McCabe and Trevino (1996) surveyed approximately 1800 students at nine medium to large U.S. state universities (all of which had participated in Bowers' 1964 study). They found that while overall the number of students who reported having engaged in at least one cheating behaviour had not increased dramatically, the number of students who reported engaging in serious test cheating behaviours had increased substantially (McCabe \& Trevino, 1996, p. 31). Incidents of copying from another student had increased from $26 \%$ to $52 \%$, assisting another student in cheating had increased from 23\% to 37\%, and the use of crib notes had increased from $16 \%$ to $27 \%$. They also reported a dramatic increase (from 11\% to 49\%) in unauthorized student collaboration (i.e., students working collaboratively when the professor explicitly asked for individual work). McCabe and Trevino concluded that "although the number of students who cheat has increased only modestly, the students who do cheat are engaging in a wider variety of test cheating behaviours today and are also cheating more often" (p. 31).

Several studies have also found that academic misconduct is very common amongst university-bound high school students. In a multi-campus survey of over 6000 students from 35 U.S. universities, Davis et al. (1992) found that between 51\% and 83\% of university students reported having cheated in high school. Similarly, Davis and Ludvigson (1995) surveyed 2,153 upper year students at 71 U.S. universities. In their study, self-reported cheating rates while at high school ranged from $71 \%$ to $79 \%$. They also found that virtually all students (99\%) who reported cheating on several occasions in university had also cheated on several occasions in high school.

Maturity appears to be one characteristic associated with high rates of student cheating during high school and amongst undergraduate students. For example, older students who are married, employed and financially independent have generally been found to report lower levels of cheating in studies which have examined individual student characteristics or personal factors (see for example, Aronson \& Mettee, 1968; Bowers, 1964; Davis et al., 1992; Davis \& Ludvigson, 1995; Eisenberger \& Shank , 1985; Haines et al. 1986; Hetherington \& Feldman, 1964; Johnson \& Gormly, 1971; McCabe \& Trevino, 1993, 1997; McCabe, Trevino, \& Butterfield, 1999, 2001; Smith, Ryan, Diggins, 1972; Steininger, Johnson, Kirts, 1964; Ward, 1987).

Arguing that little can be done about individual student differences, such as maturity, others have focused on institutional characteristics. As institutional characteristics can be influenced by administrators and faculty, it is these factors that should be given primary consideration in efforts to encourage academic integrity. One such institutional factor is the quality of the educational experience. Steininger, Johnson and Kirts (1964) surveyed 49 psychology students at one U.S. university and found an association between academic misconduct and student interest in the course, quality of the professor, and the assessment approach (i.e., meaningfulness and perceived degree of difficulty). The study was replicated 
by Johnson and Klores (1968), who found similar results. Underscoring the importance of meaningful assessment as part of the educational experience, Davis and Ludvigson (1995) argued that academic integrity would be enhanced if students were provided with tasks requiring real effort. "Long-term training in effortful tasks contributes to durable industriousness, a work ethic that naturally resists cheating" (p. 120). Hunt (2003) further suggested that academic misconduct is associated with an assessment system that prioritizes grades and credentialism over student learning:

If I wanted to learn how to play the guitar, or improve my golf swing, or write HTML, "cheating" would be the last thing that would ever occur to me. It would be utterly irrelevant to the situation. On the other hand, if I wanted a certificate saying that I could pick a jib, play a round in under 80, or produce a slick Web page (and never expected actually to perform the activity in question), I might well consider cheating (and consider it primarily a moral problem). This is the situation we've built for our students: a system in which the only incentive or motives anyone cares about are marks, credits and certificates. (p.3)

There is some evidence that the academy is willing to consider alternative approaches to assessment. For example, at some U.S. universities, and in medical schools in particular, a pass/fail assessment approach is now being used. The extent to which Canadian colleges and universities may be willing to follow suit is not yet clear.

Another institutionally-related explanation is that many students perceive little risk of being caught or penalized, with good reason. For example, in a study by Haines et al. (1986), the majority of students reported having engaged in academic misconduct while only $1 \%$ reported being caught. These findings are consistent with the more recent work of Montgomerie and Birkhead (2005) who suggested that academic misconduct is more likely to occur when associated risks are perceived to be relatively low and rewards are perceived to be relatively high, leading to a positive cost-benefit assessment.

One contributing factor to a positive cost-benefit assessment (particularly a low risk assessment) is that few students are prepared to report the cheating of their peers, even when institutional policy requires them to do so (Jendrek, 1992). Further, even some faculty look the other way when cheating occurs. Jendrek (1989) found that of the $60 \%$ of faculty who reported having witnessed academic misconduct, only $65 \%$ had penalized the student and, contrary to university policy, only $20 \%$ had reported the incident. McCabe (1993) similarly concluded that between 47 and 60\% of faculty go "to little or very little effort to document an incident" (p. 343) of academic misconduct.

The lack of action on the part of faculty may be due to several reasons including the lack of evidence and the time and effort that amassing such evidence requires (Alschuler \& Blimling, 1995; McCabe, 1993). Other potential factors include lack of knowledge of correct procedures, ineffective penalties 
and invigilation practices, a lack of support for those who bring cases forward, and personal discomfort associated with confronting a student (Alschuler \& Blimling, 1995; Pavela, 1997; Schneider, 1999).

To encourage higher risk assessments, some (see for example, Aaron \& Georgia, 1994; Kibler, 1994) have suggested that institutions could do much more to educate faculty, TAs, and students on the importance of academic integrity and to encourage them to follow associated policies and practices when it does occur. Presumably, if effective policies are consistently implemented and penalties are assigned, the perceived risks of engaging in academic misconduct will increase.

The current study attempts to determine if similar behaviours and explanations are prevalent in Canada.

\section{METHODOLOGY}

A modified version of the survey utilized in the Center for Academic Integrity's Assessment Project (see, for example, McCabe, Trevino, \& Butterfield, 2002) was used to collect data from 11 Canadian higher education institutions between January 2002 and March 2003. Participating institutions were from five provinces and represented a variety of institutional types (degree granting college, primarily undergraduate, comprehensive, and doctoral/medical). Although the core questions used in the survey were consistent across institutions, there was some variation due to individual preferences. For example, 10 of the institutions wanted additional types of student cheating added to the original survey. Where relevant, these changes are noted when discussing the results.

Each institution was encouraged to advertise the project broadly and an e-mail message inviting participation was distributed to each institution's entire academic population (undergraduate students, graduate students, TAs, and faculty). ${ }^{1}$ The e-mail message assured participants of their anonymity and contained a link to an on-line survey housed at Rutgers University. Response rates ranged from approximately 5 to 25\%. Completed surveys were submitted by 14,913 undergraduate students (including 1,269 first year students from four universities, who were asked to reflect on their high school experiences), 1,318 graduate students, 683 TAs, and 1,902 faculty. See Table 1 for additional demographic information.

In addition to these low to modest response rates, this study had several limitations which should be taken into account when interpreting the results. The data are self-reported and therefore reflect people's perceptions; the survey was accessible to anyone who had the appropriate web address (although there was no indication of abuse at any school); there was no automated control to prevent duplicate entries (although only a very small number, which seemed to be accidental, were detected); and participant concerns about confidentiality and social desirability effects may have caused some respondents to understate their engagement in various activities. In addition, the survey treated all respondents equally and therefore the results do not take into account the opportunity to 


\begin{tabular}{|c|c|c|c|c|c|c|}
\hline \multicolumn{7}{|c|}{$\begin{array}{l}\text { Table } 1 \\
\text { Participant Demographics }\end{array}$} \\
\hline Variable & & $\begin{array}{l}\text { High } \\
\text { School }\end{array}$ & Undergrads & Grads & TAs & Faculty \\
\hline \multirow[t]{2}{*}{ Number } & & 1,269 & 13,644 & 1,318 & 683 & 1,902 \\
\hline & & $\%$ & $\%$ & $\%$ & $\%$ & $\%$ \\
\hline \multirow[t]{2}{*}{ Gender } & Female & 57 & 66 & 62 & 57 & 43 \\
\hline & Male & 43 & 34 & 39 & 43 & 58 \\
\hline \multirow[t]{3}{*}{ Age } & $<20$ & 81 & 22 & $<1$ & - & - \\
\hline & $20-25$ & 16 & 69 & 40 & - & - \\
\hline & $>25$ & 4 & 10 & 60 & - & - \\
\hline \multirow[t]{4}{*}{ Year Level } & First & 100 & 24 & - & - & - \\
\hline & Second & & 25 & - & - & - \\
\hline & Third & & 24 & - & - & - \\
\hline & Fourth+ & & 28 & - & - & - \\
\hline \multirow[t]{3}{*}{ Discipline } & $\begin{array}{l}\text { Arts and } \\
\text { Humanities }\end{array}$ & 32 & 39 & 17 & 31 & 24 \\
\hline & $\begin{array}{l}\text { Math and } \\
\text { Science }\end{array}$ & 27 & 18 & 21 & 35 & 21 \\
\hline & $\begin{array}{l}\text { Professional } \\
\text { Programs/Other }\end{array}$ & 41 & 43 & 62 & 34 & 55 \\
\hline \multirow[t]{3}{*}{ Accommodation } & Residence & 23 & 23 & 6 & - & - \\
\hline & With Parents & 56 & 40 & 28 & - & - \\
\hline & Other & 21 & 38 & 66 & - & - \\
\hline $\begin{array}{l}\text { Canadian } \\
\text { Citizenship }\end{array}$ & & - & 95 & 85 & 88 & 91 \\
\hline \multirow[t]{4}{*}{ Faculty Rank } & Assistant & - & - & - & - & 21 \\
\hline & Associate & - & - & - & - & 24 \\
\hline & Full & - & - & - & - & 28 \\
\hline & Other & - & - & - & - & 27 \\
\hline \multirow[t]{3}{*}{$\begin{array}{l}\text { \# Years } \\
\text { Teaching }\end{array}$} & $<5$ & - & - & - & & 22 \\
\hline & $5-14$ & - & - & - & & 34 \\
\hline & $15+$ & - & - & - & & 44 \\
\hline \multirow[t]{3}{*}{$\begin{array}{l}\text { \# Semesters } \\
\text { TAing }\end{array}$} & 1 or 2 & - & - & - & 46 & - \\
\hline & 3 or 4 & - & - & - & 26 & - \\
\hline & $5+$ & - & - & - & 28 & - \\
\hline
\end{tabular}


engage in various behaviours that would be influenced by such factors as the number of courses taken or the number of times a student was asked to engage in a particular form of assessment. As a result of these limitations, the findings of this study should not be used to make definitive claims about the state of academic misconduct within Canada, but rather as indicators of potential areas of concern and action.

Three student surveys were developed: In the "high school" survey, first year students were asked to respond on the basis of their behaviour during high-school; in the "undergrads" survey, undergraduate students from all year levels were asked to respond on the basis of their behaviour within the past year. and in the "grads" survey, graduate students from all year levels were asked to respond on the basis of their behaviour within the past year The students were presented with a list of 25 questionable behaviours (at one institution only 17 of the 25 behaviours were presented) (see Table 2). The respondents were asked how often they had engaged in each behaviour (never, once, more than once, or not applicable) ${ }^{2}$ and to what extent they considered each behaviour cheating (not cheating, trivial cheating, moderate cheating, or serious cheating). ${ }^{3}$ They were also asked a series of questions pertaining to the behaviours of other students and the academic environment in general. At five of the participating institutions, students were also asked specifically about the assessment of their work. Faculty and TAs were asked to what extent they considered each of the 25 behaviours cheating and about their experiences in dealing with academic misconduct.

\section{RESULTS}

The results presented below pertain to similarities and differences in perceptions of what constitutes academic misconduct, the behaviours and perceptions reported by students from each of the three student groups, and the behaviours and perceptions reported by faculty and teaching assistants.

\section{Perceptions of What Constitutes Academic Misconduct}

There was considerable agreement amongst participants as to what constituted academic misconduct. The majority of respondents from all five response groups (high school, undergrads, grads, TAs, and Faculty) rated only one behaviour - sharing an assignment with another student so s/he has an example to work from (see Table 2) - as not cheating or trivial cheating. Of the remaining 24 behaviours, 18 were rated by the majority of respondents from all response groups as moderate or serious cheating. However, six behaviours were rated as not cheating or trivial cheating by the majority of respondents from one or more of the student groups (high school, undergrad and/or grad) and as moderate or serious cheating by the majority of TAs and faculty. These behaviours were as follows: working on an assignment with others when the instructor asked for individual work, receiving forbidden help on an assignment, hiding library or course materials, fabricating or falsifying lab data, using a 
false excuse to obtain an extension on a due date, and getting questions and answers from someone who has already taken a test.

\section{High School Student Behaviours and Perceptions}

The majority (58\%) of first year students completing the high school survey reported one or more instances of serious test cheating while in high school (see Table 3). Consistent with McCabe's earlier work, serious cheating is defined here as copying from another student with or without his or her knowledge, helping another student cheat on a test, and using unauthorized crib notes. As previously noted, the majority of respondents from all five response groups agreed that each of these behaviours constituted moderate or serious cheating.

Approximately three-quarters (73\%) also reported one or more instances of serious cheating on written work while in high school (see Table 3). Again, the definition of serious cheating used here is consistent with McCabe's earlier work in which serious cheating was defined as copying a few sentences of material from a written source or the Internet without footnoting, copying material almost word for word from a written source and turning it in as your own, turning in work done by someone else, fabricating or falsifying a bibliography, and turning in a paper obtained either for free or purchased from a paper mill or website. The majority of respondents from all five response groups agreed that each of these behaviours constituted moderate or serious cheating.

The five most common cheating behaviours reported by university students while in high school were working with others when asked for individual work (76\%), getting questions and answers from someone who had already taken a test (73\%), copying a few sentences of written material without footnoting (62\%), copying a few sentences from the Internet without footnoting (57\%), and fabricating or falsifying lab data (50\%) (see Table 4). ${ }^{4}$ In addition, almost all of the listed cheating behaviours ( 21 out of 24 ) were reported by at least $10 \%$ of the respondents.

Consistent with these high rates, student responses revealed an environment in which there was little perceived risk or social stigma associated with their actions. Only $12 \%$ agreed or strongly agreed that students who cheated during high school would be embarrassed to tell their friends they had done so, only $13 \%$ thought it likely or very likely that a student would report an incident of cheating, only $14 \%$ agreed that students who cheated were likely to be caught, and less than half (43\%) agreed that students who were caught cheating would be given significant penalties for having done so. Given these results, it is perhaps not surprising that only $21 \%$ agreed that cheating was a serious problem at their high school.

The good news for university faculty and administrators is that these same students expected things to be different at university. Based on their initial impressions of university life, $80 \%$ agreed or strongly agreed that university instructors try hard to discourage cheating, 54\% agreed or strongly agreed that university students who cheat would be embarrassed to tell their friends that they 


\begin{tabular}{|c|c|c|c|c|c|}
\hline \multicolumn{6}{|l|}{$\begin{array}{l}\text { Table } 2 \\
\text { Perceptions of Seriousness For } 25 \text { Specific Behaviours }\end{array}$} \\
\hline \multirow[t]{2}{*}{ Specific Behaviours } & \multicolumn{5}{|c|}{$\begin{array}{l}\text { \% Rating behaviour as "not cheating" or } \\
\text { "trivial cheating" }\end{array}$} \\
\hline & $\begin{array}{l}\text { High- } \\
\text { school }\end{array}$ & Undergrads & Grads & TAs & Faculty \\
\hline & $\%$ & $\%$ & $\%$ & $\%$ & $\%$ \\
\hline $\begin{array}{l}\text { Sharing an assignment with another students, so } \\
\text { they have an example to work from** }\end{array}$ & 82 & 80 & 73 & 61 & 57 \\
\hline $\begin{array}{l}\text { Working on an assignment with others when the } \\
\text { instructor asked for individual work }\end{array}$ & 80 & 79 & 63 & 49 & 27 \\
\hline Receiving unpermitted help on assignment & 72 & 70 & 52 & 47 & 27 \\
\hline Hiding library or course materials* & 54 & 49 & 33 & 33 & 22 \\
\hline Fabricating or falsifying lab data* & 51 & 36 & 12 & 13 & 3 \\
\hline $\begin{array}{l}\text { Using false excuse to obtain extension on due } \\
\text { date }\end{array}$ & 50 & 46 & 41 & 38 & 24 \\
\hline Getting Q/A from someone who has taken test & 47 & 50 & 30 & 22 & 13 \\
\hline Fabricating or falsifying a bibliography & 47 & 44 & 25 & 23 & 12 \\
\hline Damaging library or course materials* & 46 & 43 & 29 & 31 & 22 \\
\hline $\begin{array}{l}\text { Copying a few sentences from an Internet source } \\
\text { w/o footnoting them in the paper }\end{array}$ & 45 & 48 & 36 & 32 & 28 \\
\hline $\begin{array}{l}\text { Copying a few sentences of material from a } \\
\text { written source w/o footnoting them in the paper }\end{array}$ & 44 & 46 & 33 & 31 & 28 \\
\hline Fabricating or falsifying research data* & 37 & 18 & 6 & 4 & 2 \\
\hline $\begin{array}{l}\text { In a course requiring computer work, copying a } \\
\text { friend's program rather than doing your own }\end{array}$ & 23 & 19 & 10 & 7 & 5 \\
\hline Turning in work done by someone else & 21 & 18 & 9 & 7 & 3 \\
\hline $\begin{array}{l}\text { Provide a previously graded assignment to } \\
\text { someone to submit as their own work* }\end{array}$ & 17 & 12 & 7 & 5 & 3 \\
\hline Turning in a paper copied from another student & 16 & 15 & 7 & 4 & 2 \\
\hline $\begin{array}{l}\text { Turning in a paper obtained in large part from a } \\
\text { Term paper "mill"/web site that did not charge" }\end{array}$ & 14 & 10 & 8 & 4 & 1 \\
\hline $\begin{array}{l}\text { Turning in a paper obtained in large part from a } \\
\text { Term paper "mill”/web site that did charge* }\end{array}$ & 14 & 9 & 8 & 4 & 1 \\
\hline Helping someone else cheat on a test & 13 & 11 & 7 & 4 & 3 \\
\hline Writing or providing a paper for another student & 13 & 12 & 6 & 3 & 2 \\
\hline $\begin{array}{l}\text { Altering a graded test to try to get additional } \\
\text { credit }\end{array}$ & 12 & 10 & 8 & 6 & 3 \\
\hline $\begin{array}{l}\text { Copying from another student during a test with } \\
\text { his or her knowledge }\end{array}$ & 11 & 8 & 6 & 3 & 2 \\
\hline $\begin{array}{l}\text { Copying material almost word for word from a } \\
\text { written source and turning it in as your own }\end{array}$ & 11 & 7 & 6 & 2 & 2 \\
\hline Using unpermitted crib notes during a test & 11 & 8 & 6 & 3 & 1 \\
\hline $\begin{array}{l}\text { Copying from another student during a test } \\
\text { without his or her knowledge }\end{array}$ & 8 & 7 & 5 & 2 & 3 \\
\hline
\end{tabular}

*Question was not included in the survey used by one institution - results reflect responses from 10 institutions only

Shading represents behaviours for which there is majority disagreement (e.g., majority of students from at least one group rated the behaviour as not cheating or trivial cheating, while the majority of TAs and faculty rated the behaviour as moderate or serious cheating. 


\section{Table 3}

A Comparison of Rates of Engagement in Serious* Test Cheating and Serious* Cheating in Written Work

\begin{tabular}{|c|c|c|c|}
\hline Type of Cheating & $\begin{array}{l}\text { High } \\
\text { School } \\
(\%)\end{array}$ & $\begin{array}{l}\text { Under- } \\
\text { grads } \\
(\%)\end{array}$ & $\begin{array}{c}\text { Grads } \\
(\%)\end{array}$ \\
\hline Serious Test Cheating & 58 & 18 & 9 \\
\hline $\begin{array}{l}\text { - copying from another student with or } \\
\text { without his or her knowledge } \\
\text { - helping another student to cheat on a test } \\
\text { - } \text { using unauthorized crib notes }\end{array}$ & & & \\
\hline Serious Cheating in Written Work & 73 & 53 & 35 \\
\hline $\begin{array}{l}\text { - copying a few sentences of material from } \\
\text { a written source or the Internet without } \\
\text { footnoting } \\
\text { - copying material almost word for word from } \\
\text { a written source and turning it in as your } \\
\text { own, turning in work done by someone else } \\
\text { - fabricating or falsifying a bibliography } \\
\text { - turning in a paper obtained either for free or } \\
\text { purchased from a paper mill or website }\end{array}$ & & & \\
\hline
\end{tabular}

*Serious academic misconduct behaviours as defined by McCabe, Trevino \& Butterfield (2001)

had done so, 52\% agreed or strongly agreed that students who cheat at university are likely to be caught, and $87 \%$ agreed or strongly agreed that university students who are caught cheating will be given significant penalties for doing so.

\section{Undergraduate Student Behaviours and Perceptions}

While few undergraduate students (18\%) reported having engaged in one or more instances of serious test cheating behaviour (as previously defined) during the past year, the majority (53\%) reported having engaged in one or more instances of serious cheating on written work (as previously defined) (see Table 3). Forty-five percent of these undergraduate students reported that they were certain another student had cheated during a test or exam during the past year, and another 20\% indicated they suspected such cheating. This suggests that some of these rates may be understated, particularly for serious test cheating.

The five most common cheating behaviours reported by the undergraduate students were the same as for the high-school students, although the percentage of students who reported engaging in each was substantially lower. These behaviours include the following: working with others when asked for individual work (45\%), getting questions and answers from someone who has already taken a test (38\%), copying a few sentences of material from a written source without footnoting (37\%), copying a few sentences from the Internet without footnoting (35\%), and fabricating or falsifying lab data (25\%) (see Table 4). 
Again, despite these high rates, few students (only 18\%) agreed or strongly agreed that "cheating is a serious problem here."

With respect to context, the majority of students perceived some aspects of the environment to be supportive of academic integrity. For example, 67\% perceived the penalties for cheating to be high or very high, 78\% perceived faculty support of policies concerning cheating to be high or very high, and $89 \%$ reported having been informed about these policies. Of those who had been informed, 56\% said they had learned "a lot" from faculty whereas only $25 \%$ had learned "a lot" from the university calendar. However, only $44 \%$ of students perceived the effectiveness of academic misconduct policies to be high or very high, only $34 \%$ perceived judicial processes to be fair and impartial, and only $13 \%$ thought it likely or very likely that a typical student would report an incident of cheating they observed.

With respect to assessment, results were generally positive. Fifty-eight percent agreed or strongly agreed that "faculty change exams/ assignments on a regular basis," 58\% agreed or strongly agreed that "assessments used are effective in evaluation," 60\% agreed or strongly agreed that "assessments help me learn course concepts," 73\% agreed or strongly agreed that "difficulty of exams etc. is appropriate for my level," and 74\% agreed or strongly agreed that "course work is reasonable for my level/program."

\section{Graduate Student Behaviours and Perceptions}

Substantially fewer graduate students (only 9\%) reported having engaged in one or more instances of serious test cheating behaviour, while a surprisingly high number (35\%) reported having engaged in one or more instances of serious cheating on written work (see Table 3). Once again, our findings suggest that these rates may be understated as many graduate students (37\%) reported they were certain another student had cheated in a test or exam during the past year and another 19\% indicated they suspected such cheating.

Four of the five most common behaviours were the same as for high-school and undergraduate students (although once again reported rates of engagement were lower): working with others when asked for individual work (29\%), copying a few sentences from written material without footnoting (24\%), copying a few sentences from the Internet without footnoting (22\%), and getting questions and answers from someone who has already taken a test (16\%) (see Table 4). The fifth most common behaviour for graduate students was receiving unauthorized help on an assignment (10\%). While fabrication or falsification of lab data was reported by only $6 \%$ of graduate students, this is still a sobering percentage given the nature of the work with which graduate students are involved and the fact that in their work as teaching assistants or as future academics, they may be expected to act on incidents of cheating. Almost a quarter of graduate students $(24 \%)$ agreed or strongly agreed "cheating is a serious problem here."

In terms of overall context, once again, results were mixed: $46 \%$ of graduate students perceived the penalties for cheating to be high or very high, 65\% 
perceived faculty support of policies concerning cheating to be high or very high, and 77\% reported having been informed about these policies. For those who had been informed, 34\% said they had learned "a lot" from faculty while $20 \%$ said they had learned "a lot" from the University calendar. Unfortunately, only $30 \%$ perceived these policies to be highly or very highly effective. Further, only $27 \%$ perceived judicial processes to be fair and impartial, and only $18 \%$ thought it likely or very likely that a typical student would report a violation.

With respect to assessment, once again results were generally positive. Seventy percent agreed or strongly agreed that "assessments used are effective in evaluation," $72 \%$ agreed or strongly agreed that "assessments help me learn course concepts," $81 \%$ agreed or strongly agreed that "difficulty of exams etc. is appropriate for my level," and 84\% agreed or strongly agreed that "course work is reasonable for level/program." However, only 50\% agreed or strongly agreed that "faculty change exams/assignments on a regular basis."

\section{Faculty and TA Behaviours and Perceptions}

Many faculty (75\%) and TAs (80\%) reported having suspected a case of student cheating on a test or exam during the past year and almost half were sure cheating had actually occurred (46\% of faculty and $49 \%$ of TAs). However, less than half believed student cheating to be a serious problem (43\% of faculty and $42 \%$ of TAs agreed or strongly agreed that "cheating is a serious problem here").

In response to suspected cases of academic misconduct, many faculty $(46 \%)$ and TAs (38\%) reported having ignored the incident. The dominant explanation was the lack of evidence or proof (85\% faculty and 79\% of TAs). Other explanations included the following: lack of support from administration (20\% faculty, 16\% TAs); lack of time to pursue suspected cases (20\% faculty, $13 \% \mathrm{TAs}$ ); and the trivial nature of the offence (20\% faculty, 24\% TAs). Other TA explanations included the following: they were told to ignore it by faculty member (18\%) and they did not want to deal with it (16\%).

If convinced that a student had cheated on a major test or assignment, however, the vast majority of faculty (98\%) and TAs (99\%) indicated that they would take action. Although it is unclear exactly what action they should take, as data were not collected on individual institution's policies, faculty suggested that their typical responses would include actions such as reporting the student to the department chair or dean (53\%), failing the student on the test or assignment (45\%), and/or giving the student a warning (35\%). ${ }^{5}$ Common TA responses included the following: reporting the student to the faculty member in charge of the course (77\%), discussing the incident with other TAs (37\%), reprimanding or warning the student (34\%), and failing the student on the test or assignment (29\%).

These variations in response may be indicative of a lack of awareness of institutional procedures or a lack of willingness to follow them. Furthermore, the high percentage of faculty and TAs who indicated they would give a warning (particularly if such warnings are not accompanied by a formal record of such), may serve to reinforce a low risk assessment. With no formal record, a student 
Table 4

Self-reported Student Engagement in 25 Specific Behaviours

\begin{tabular}{|c|c|c|c|}
\hline \multirow[t]{2}{*}{ Specific Behaviours } & \multicolumn{3}{|c|}{$\begin{array}{l}\text { \% of Students Reporting Having } \\
\text { Engaged in Behaviour at least once }\end{array}$} \\
\hline & $\begin{array}{l}\text { High } \\
\text { School }\end{array}$ & Undergrads & Grads \\
\hline $\begin{array}{l}\text { Sharing an assignment with another students, so they } \\
\text { have an example to work from* }\end{array}$ & 86 & 66 & 52 \\
\hline $\begin{array}{l}\text { Working on an assignment with others when the } \\
\text { instructor asked for individual work }\end{array}$ & 76 & 45 & 29 \\
\hline Getting Q/A from someone who has taken test & 73 & 38 & 16 \\
\hline $\begin{array}{l}\text { Copying a few sentences of material from a written } \\
\text { source w/o footnoting them in the paper }\end{array}$ & 62 & 37 & 24 \\
\hline $\begin{array}{l}\text { Copying a few sentences from an Internet source w/o } \\
\text { footnoting them in the paper }\end{array}$ & 57 & 35 & 22 \\
\hline Fabricating or falsifying lab data* & 50 & 25 & 6 \\
\hline Receiving unpermitted help on an assignment & 45 & 18 & 10 \\
\hline Helping someone else cheat on a test & 41 & 8 & 4 \\
\hline Using false excuse to obtain extension on due date & 34 & 12 & 9 \\
\hline $\begin{array}{l}\text { Copying from another student during a test with his } \\
\text { or her knowledge }\end{array}$ & 33 & 6 & 3 \\
\hline Fabricating or falsifying a bibliography & 30 & 17 & 9 \\
\hline Using unpermitted crib notes during a test & 30 & 6 & 4 \\
\hline Fabricating or falsifying research data* & 29 & 9 & 3 \\
\hline $\begin{array}{l}\text { Copying from another student during a test without } \\
\text { his or her knowledge }\end{array}$ & 28 & 8 & 3 \\
\hline $\begin{array}{l}\text { In a course requiring computer work, copying a } \\
\text { friend's program rather than doing your own }\end{array}$ & 27 & 14 & 7 \\
\hline Turning in work done by someone else & 22 & 9 & 4 \\
\hline $\begin{array}{l}\text { Copying material almost word for word from a } \\
\text { written source and turning it in as your own work }\end{array}$ & 20 & 5 & 3 \\
\hline $\begin{array}{l}\text { Providing a previously graded assignment to } \\
\text { someone to submit as their own work* }\end{array}$ & 19 & 8 & 5 \\
\hline Turning in a paper copied from another student & 16 & 8 & 3 \\
\hline Writing or providing a paper for another student & 15 & 5 & 4 \\
\hline Hiding library or course materials* & 10 & 4 & 4 \\
\hline Altering graded test to try to get additional credit & 10 & 2 & 1 \\
\hline $\begin{array}{l}\text { Turning in a paper obtained in large part from a } \\
\text { Term paper "mill"/web site that did not charge* }\end{array}$ & 9 & 2 & 1 \\
\hline Damaging library or course materials* & 4 & 2 & 2 \\
\hline $\begin{array}{l}\text { Turning in a paper obtained in large part from a } \\
\text { Term paper "mill"/web site that did charge * }\end{array}$ & 1 & 1 & 0 \\
\hline
\end{tabular}

*Question was not included in the survey used by one institution - results reflect responses from 10 institutions only 
could continue to engage in academic misconduct and if and when formal action is taken, would likely be treated as a "first time" offender.

The majority of faculty (65\%) who had referred a suspected case of cheating to the administration for resolution reported being satisfied or very satisfied with how the case was handled. This was not the case for TAs, however, with only 39\% reporting being satisfied or very satisfied.

Faculty and TAs were also asked about what penalties a student would most likely receive if he or she was found guilty of cheating on a major test or assignment. The most likely action (indicated by 59\% of faculty and 71\% of TAs) was a reprimand or warning. In contrast, the majority of faculty (56\%) and TAs (59\%) indicated they would most prefer to have the student receive a failing grade for the exam or assignment.

In an effort to curb student cheating, faculty reported implementing various safeguards in their courses. The most common practices included closely monitoring students taking exams (74\%), regularly changing exams (75\%), providing information on their course outlines about cheating/plagiarism (66\%), and discussing the importance of honesty and integrity with their students (52\%). Indicative of an emerging trend, $22 \%$ of faculty and 20\% of TAs also reported turning to the Internet and plagiarism detection software such as Turnitin.com to help confirm plagiarism. The use of Turnitin.com was highest among faculty in the Arts (39\%) and Social Sciences (37\%) and notably lower among Agriculture (2\%) and Nursing (6\%) faculty.

Despite these measures, only $11 \%$ of faculty and 17\% of TAs rated student understanding of campus policies concerning cheating as high or very high. And, only $12 \%$ of faculty and $17 \%$ of TAs perceived the effectiveness of these policies to be high or very high. One explanation for the perceived low level of student understanding is that the majority of faculty (65\%) and TAs (56\%) reported having only a "low" or "moderate" understanding of these policies themselves. A related issue may be the low level of discussion about academic integrity policies that reportedly occurs amongst faculty and between faculty and university administrators. Less than one-third of faculty reported having learned about their university's academic integrity policies through discussions with other faculty $(33 \%)$, their department chair $(26 \%)$, or their dean or other administrators (26\%). Instead, the majority of faculty (58\%) reported having learned about their university's academic misconduct policies by reading their university calendars, suggesting that faculty and TAs who do not take this initiative may remain largely ignorant of their institution's policies and procedures for dealing with academic misconduct.

\section{DISCUSSION}

As previously suggested, due to several methodological limitations, the findings of this study should not be used to make definitive claims about the state of academic misconduct within Canada, but rather as indicators of potential areas of concern and action. 
Overall, these results suggest that many Canadian university students may have engaged in various forms of academic misconduct, particularly in high school, but also in their written work as undergraduate students and also as graduate students. Although the amount of academic misconduct that was reported to occur in university is less than that in high school, it is still problematic. These findings are consistent with the literature which suggests that student maturity might be associated with rates of engagement in academic misconduct.

With respect to the most common behaviours, student opinion as to what constitutes cheating may be an important factor. Four of the six behaviours that the majority of students from one or more of the student groups (high school, undergrads, grads) viewed as not cheating or trivial cheating were also found in the list of behaviours in which students reported having engaged most often. For example, many students from all three groups reported engaging in various collaborative behaviours such as working with others when asked for individual work and getting unauthorized help on an assignment. Faculty viewed these behaviours much more seriously. These results may represent a clash between an emerging collaborative student culture and a more traditional, individualistic faculty culture. Many students have arguably come to realize that working collaboratively can be time-efficient and learning-effective, and can lead to higher grades for everyone involved. In contrast, traditional assessment practice tends to focus on differentiating one student from another in support of various grades-based decisions, such as who should receive a scholarship or gain entrance to graduate school.

Given a student culture that values collaboration, faculty should be realistic when assigning independent work and be clear about their rationale for doing so. For example, the requirement that students work individually on an assignment for which there is only one right answer is not likely to be adhered to by many in an unsupervised setting. In recognition of this reality, some Canadian faculty are now encouraging their students to work independently when appropriate (e.g., in an on-line quiz) explaining that they will be better prepared for the final exam if they do so. They do not, however, require independent work or endeavour to penalize students who elect to work collaboratively.

Many students also reported "collaborating" with others by obtaining questions and answers in advance of writing a test or exam. This behaviour is consistent with the practice reported by $25 \%$ of faculty of not changing exams on a regular basis. In support of a culture of integrity, faculty may need to either substantially change their exams between semesters or "level the playing field" by making them available in advance to all students as a study aid. For courses with multiple sections, faculty need to either create different exams or have all students write the same exam at the same time. The latter will require administrative support with respect to room availability and invigilation/ proctoring. Effective policies may also be needed for dealing with students who miss an exam. Ideally, a comparable but not identical exam would be used. As 
noted earlier, perceptions of any unfairness in the assessment process appears to be a significant justification for cheating in the mind of many students. It is clear that when students perceive game playing conditions, such as when an old exam is available to a select few, that students are more likely to engage in game playing behaviour. That is, rather than focusing their efforts on learning the course material in general, they will focus their efforts on securing a copy of the old exam and memorizing the desired answers.

Many students also reported helping someone else cheat on a test during high school. This suggests that much more may need to be done to ensure the effective invigilation of test and exams in these settings. Perhaps greater collaboration is needed between high schools and universities for dealing with this issue. As suggested by Cole and Kiss (2000) in reference to Aristotle, "moral character is formed by habitual action. The longer students spend in environments that support cheating, the more prone they will be to developing long-term habits of cheating" (p.6).

In addition to issues of student collaboration, the survey results suggest that much more work may need to be done to educate undergraduate and graduate students about why fabricating or falsifying lab or research data are anathema to the values of academe. Faculty can minimize the opportunity or temptation for students to engage in these behaviours by ensuring that laboratory assignments and research projects are sufficiently different from term to term and encouraging the honest reporting of data (e.g., carefully scrutinizing submitted work, not penalizing students for getting unexpected results, and/or providing students with multiple attempts to get the "right" result). Also, faculty need to ensure that adequate equipment is available for students to successfully complete assigned labs, so that students are not tempted to falsify results in order to compensate for faulty equipment.

With respect to fabricating or falsifying a bibliography, students may also benefit from being educated about information literacy. They need to be taught effective citation practices (how to cite and why it is important), strategies for finding useful references, and how to keep track of works cited or paraphrased. To further encourage legitimate referencing, faculty can require drafts (which can help students avoid last minute work) and annotated bibliographies and copies of the references used.

Given the extent to which the students reported engaging in academic misconduct, it is perhaps surprising that student views of assessment were generally positive; that is, the majority of undergraduate and graduate students indicated that their assessments were effective in helping them learn. Further research is needed to explore whether there is a statistical association between student views on assessment and rates of engagement in academic misconduct behaviours.

In addition to the possible explanations just reviewed, there is another possible reason for the cheating behaviours reported by Canadian students. The perceived low risk of being caught or penalized may lead students to conclude that a positive cost-benefit exists. Our findings support this explanation: 
many students reported that a typical student would be unwilling to report an incident of academic misconduct he or she observed, many faculty and TAs reported having ignored suspected cases (due primarily to lack of evidence), and a reprimand or warning was given as the most likely action that would be taken if a student was found guilty of academic misconduct on a major test or assignment. All of these factors may be contributing to repeat offences.

Perhaps contributing further to the perceived low risk level, undergraduate students, graduate students, TAs, and faculty reported little confidence in the effectiveness of their institution's academic misconduct policies and procedures. Also, many TAs who had referred a case of cheating to the administration reported being dissatisfied or very dissatisfied with how the case was handled. Although the survey did not explore specifically why this might be the case, anecdotal evidence suggests that this may be because so little action is taken by faculty and by the administration when cheating is reported by TAs. Also, respondents reported low levels of understanding of academic misconduct policies on the part of themselves and/or others. Efforts to actively educate faculty on these policies was low, with posting information in the university calendar being the primary means of communication. This may signal a lack of institutional commitment to ensure faculty and TAs are fully educated about this important issue.

In order to address these problems, we suggest here that institutions should recommit themselves to academic integrity and that considerable effort needs to be put into understanding where existing policies are failing. New policies and procedures (including meaningful penalties) that have the confidence of the community are clearly needed. Implementation of such policies and procedures need to be supported by system-wide educational efforts directed at administrators, faculty, TAs and students.

Combined educational efforts may also be needed between universities, colleges and high schools in an attempt to curb academic misconduct before it becomes routine. Special educational programming for incoming students may be particularly important to reinforce the message that academic misconduct will not be tolerated. One model of possible interest to Canadian universities may be the modified honour code model that that is receiving increased attention on many U.S. campuses (McCabe \& Pavela, 2000).

With more effective policies in place, an improved commitment on the part of faculty and TAs to following them and more appropriate penalties being applied, the perceived risk on the part of students may increase. Combined with the other strategies previously discussed (e.g., addressing student perceptions of what constitutes serious cheating, and improved assessment and invigilation practices), academic misconduct by Canadian students may decline.

\section{CONCLUSION}

Similar to the results of five decades of research on American undergraduate students, the current study found that large numbers of Canadian high school, 
undergraduate, and graduate students report they have engaged in a variety of questionable behaviours in the completion of their academic work. Despite the study's methodological limitations, these results are consistent with the view of over $40 \%$ of faculty and TAs: cheating may be a serious problem in Canadian higher education.

The current research suggests that many factors may be associated with these behaviours. A particularly important issue concerns beliefs about what constitutes academic misconduct. The present study found substantial differences in opinion between students and faculty for several behaviours, particularly those associated with unauthorized collaboration and falsification and fabrication behaviours. Many students may engage in these behaviours simply because they don't believe they are wrong. A related issue is assessment practice. Faculty need to ensure that their approach to assessment encourages student learning and not game-playing behaviour, such as falsifying lab results. For some students, the low perceived risk of being caught or penalized might also be a contributing factor.

Institutions of higher education need to develop comprehensive strategies for dealing with academic misconduct, beginning with the explicit recognition that there is a problem. The current research has helped make this point. However, the fact that so many Canadian universities agreed to participate in this study is a positive indication of a growing commitment to dealing with this issue. The current research focused on certain types of academic misconduct by students. Future research is needed on the types and extent of academic misconduct by faculty. Also, we need to be able to more clearly identify factors associated with academic misconduct, by both students and faculty. Finally, research is needed on the strategies that have been put in place and their effectiveness in helping enhance academic integrity within Canadian higher education.

\section{NOTES}

1 Graduate students had the opportunity to respond to a graduate student survey, a TA survey, or both.

2 In the reporting of frequencies N/A responses were treated as missing data.

3 At one institution only three categories were used - the "moderate" cheating option was not available.

4 "Sharing an assignment with another student, so they have an example to work from" was not included in this discussion as it was considered "not cheating' or 'trivial cheating' by the majority of respondents from all five response groups.

5 Participants were given the opportunity to select more than one response. 


\section{ACKNOWLEDGEMENTS}

The study was undertaken in conjunction with the Center for Academic Integrity at Duke University in a project partially underwritten by the John Templeton Foundation.

\section{REFERENCES}

Aaron, R.M., \& Georgia, R.T. (1994). Administrator perceptions of student academic dishonesty in collegiate institutions. NASPA Journal, 31(2), 83-91.

Alschuler, A.S., \& Blimling, S.B. (1995). Curbing epidemic cheating through systemic change. College Teaching, 43(4), 123-125.

Aronson, E., \& Metee, D.R (1968). Dishonest behaviour as a function of differential levels of induced self-esteem. Journal of Personality and Social Psychology, 9(2), 121-127.

Bowers, W.J. (1964). Student dishonesty and its control in college. New York, NY: Bureau of Applied Social Research, Columbia University.

Cole, S., \& Kiss, E. (2000). What can we do about student cheating? About Campus, 5, 5-12.

Davis, S.F., Grover, C.A., Becker, A.H., \& McGregor, L.N. (1992). Academic dishonesty: Prevalence, determinants, techniques, and punishments. Teaching of Psychology, 19(1), 16-20.

Davis, S.F., \& Ludvigson, H.W. (1995). Additional data on academic dishonesty and a proposal for remediation. Teaching of Psychology, 22(2), 119-121.

Eisenberger, R., \& Shank, D.M. (1985). Personal work ethic and effort training affect cheating. Journal of Personality and Social Psychology, 49(2), 520-528.

Haines, V.J., Diekhoff, G.M., LaBeff, E.E., \&, Clark, R.E. (1986). College cheating: Immaturity, lack of commitment and the neutralizing attitude. Research in Higher Education, 25(4), 342-354.

Hetherington, E.M., \& Feldman, S.E., (1964). College cheating as a function of subject and situational variables. Journal of Educational Psychology, 55(4), 212-228.

Hunt, R. (2003). Let's hear it for Internet plagarism. Teaching \& Learning Bridges, University of Saskatchewan, 2(3), 2-5.

Jendrek, M.P. (1989). Faculty reactions to academic dishonesty. Journal of College Student Development, 30, 401-406.

Jendrek, M.P. (1992). Students' reactions to academic dishonesty. Journal of College Student Development, 33, 260-273. 
Johnson, C.D. \& Gormly, J. (1971). Achievement, sociability, and task importance in relation to academic cheating. Psychology Reports, 28, 302.

Johnson, R.E., \& Klores, M.S. (1968). Attitudes towards cheating as a function of classroom dissatisfaction and peer norms. Journal of Educational Research, 62(2), 60-64.

Kibler, W.L. (1994). Addressing academic dishonesty: What are institutions of higher education doing and not doing? NASPA Journal, 31(2), 92-101.

McCabe, D. (1993). Academic integrity: What the latest research shows. Synthesis: Law and Policy in Higher Education, 5, 340 - 343.

McCabe, D.L. \& Pavela, G. (2000). Some good news about academic integrity. Change, 33(5), 32-38

McCabe, D.L., \& Trevino, L.K. (1993). Academic dishonesty: Honor codes and other contextual influences. Journal of Higher Education, 64(5), 522538.

McCabe, D.L., \& Trevino, L.K. (1996, January/February). What we know about cheating in college: Longitudinal trends and recent developments. Change, 28(1),28-33.

McCabe, D.L., Trevino, L.K. \& Butterfield (1999). Academic integrity in honor code and non-honor code environments: A qualitative investigation. Journal of Higher Education, 70(2), March/April, 211-234.

McCabe, D.L., Trevino, L.K., \& Butterfield, K.D. (2001). Cheating in academic institutions: A decade of research. Ethics \& Behaviour, 11(3), 219-233.

McCabe, D.L., Trevino, L.K., \& Butterfield (2002). Honor codes and other contextual influences on academic integrity. Research in Higher Education, 43(3), 357-378.

Montgomerie, B., Birkhead, T. (2005). A beginner's guide to scientific misconduct. International Society for Behavioral Ecology, 17(1), 16-24.

Pavela, G. (1997). Applying the power of association on campus: A model code of academic integrity. Journal of College and University Law, 24(1), 97-118.

Payne, S.L., \& Nantz, K.S. (1994). Social accounts and metaphors about cheating. College Teaching, 42(3), 90-96.

Schneider, A. (1999, January 22). Why professors don't do more to stop students who cheat. The Chronicle of Higher Education, p. 1-8.

Singhal, A.C. (1982). Factors in students' dishonesty. Psychological Reports, 51, 775-780.

Smith, C.P., Ryan, E.R. \& Diggins, D.R. (1972). Moral decision making: Cheating on examinations. Journal of Personality, 40, 640-660. 
Steininger, M., Johnson, R.E., \& Kirts, D.K. (1964). Cheating on college examinations as a function of situationally aroused anxiety and hostility. Journal of Educational Psychology, 55(6), 317-324.

Ward, D.A. (1987). Self-esteem and dishonest behaviour revisited. Journal of Social Psychology, 126(6), 709-713.

Julia Christensen Hughes is an Associate Professor and Director of Teaching Support Services at the University of Guelph and President of the Society for Teaching and Learning in Higher Education. Her research interests include academic integrity and teaching and learning effectiveness in higher education.

Don McCabe is a Professor of Management at Rutgers University and founding president of the Center for Academic Integrity at Duke University. His research focuses on issues of academic integrity and student honesty. 